\title{
COMO FAZER O MARKETING DE CAMPANHAS ANTIRRÁBICAS URBANAS: INFORMAÇÃO AOS MUNÍCIPES
}

\author{
HOW TO MARKETING ANTI RABIES CAMPAIGNS: INFORMATION \\ TO RESIDENTS \\ A. P. ALMEIDA ${ }^{1 *}$, G. C. OLIVEIRA ${ }^{1}$, V. M. C. SILVA ${ }^{2}$, R.I. SILVA ${ }^{2}$, S. D. BABBONI ${ }^{2}$, \\ E. LEGATTI ${ }^{2}$, J. R. MODOLO ${ }^{1}$, C. VICTÓRIA ${ }^{1}$
}

\section{RESUMO $^{1}$}

Diz o provérbio que "a propaganda é a alma do negócio". De fato, não apenas a propaganda, mas o marketing como um todo pode alavancar vendas. Entretanto, o marketing e a propaganda não são exclusivamente voltados ao aspecto comercial. Campanhas de vacinação antirrábica urbana, para lograr bons índices de cobertura vacinal, necessitam de um plano de marketing adequado, de recursos humanos bem preparados e de público bem informado. O objetivo deste trabalho é apresentar as estratégias de marketing e propaganda utilizadas durante a $43^{\mathrm{a}}$ Campanha de vacinação antirrábica urbana do Município de Botucatu, SP, em 2013. Um mês antes do dia da vacinação, iniciou-se uma atividade de educação em saúde intitulada "Jogo da guarda Responsável”, cujo público-alvo eram os alunos do $4^{\circ}$ ano fundamental de escolas da rede municipal de ensino; ao final, estes receberam panfletos orientando sobre as datas e locais dos postos de vacinação. Paralelamente, parte dos agentes de saúde distribuíram 45 mil panfletos casa a casa. Além disso, foram afixados um mil cartazes em locais de grande movimentação, e um outdoor. Também houve divulgação pelos meios virtuais da Vigilância Ambiental em Saúde, em um jornal local, no evento da TV Tem "Estimacão" e no desfile de 07 de setembro. No dia da vacinação, recursos audiovisuais locais foram utilizados para alertar a população; os postos (barracas azuis) eram identificados com uma faixa "Campanha de vacinação contra a Raiva. Seja responsável! Ajude a evitar a Raiva. Leve seu cão ou gato para vacinar". O índice de cobertura vacinal, apenas no perímetro urbano do Município de Botucatu/SP, foi 71,68\%, considerado bom. Ações voltadas para a saúde animal e saúde pública, em especial as atividades educativas, requerem um bom plano de marketing e ferramentas de divulgação adequadas, as quais podem auxiliar no bom êxito dos municípios.

\section{PALAVRAS-CHAVE: DIVULGAÇÃO. POPULAÇÃO. VACINAÇÃO. RAIVA}

AGRADECIMENTOS: A todos os agentes de saúde pública e a diretória da Vigilância Ambiental em Saúde - VAS, vinculada a secretária de saúde do município de Botucatu - SP, que desenvolve todo este trabalho de divulgação e educação em saúde.

ÁREA TEMÁTICA: Planejamento em Saúde Animal e Saúde Pública

\footnotetext{
${ }^{1}$ Faculdade de Medicina Veterinária e Zootecnia da Universidade Estadual Paulista (UNESP) - Campus de Botucatu * arthurpombo_mv@ hotmail.com

${ }^{2}$ Servidor da Vigilância Ambiental em Saúde, Prefeitura de Botucatu - SP.
} 